\title{
The assessment of the surface texture of friction node components after tribological tests
}

\author{
Ocena struktury geometrycznej powierzchni elementów węzła tarcia
} po badaniach trybologicznych

\section{STANIS $Ł A W$ ADAMCZAK JACEK ŚWIDERSKI TOMASZ DOBROWOLSKI*}

At present, a number of methods can be applied to measure the surface structure of elements. In this paper, following methods were selected to measure the surface texture of friction node components (a ball-disc couple) after tribological tests: contact profilometry, coherence correlation interferometry and atomic force microscopy. The specimens under in vestigation were: a disc coated by DLC (diamond-like carbon) layer and a ball made of bearing steel.

KEYWORDS: surface texture, atomic force microscopy, tribological test, diamond-like carbon coatings

Spośród wielu metod pomiarów struktury geometrycznej powierzchni w artykule przedstawiono moźliwości wykorzystania profilometrii stykowej, koherentnej interferometrii korelacyjnej i mikroskopii sił atomowych do oceny stanu powierzchni elementów węzła tarcia przed badaniami tribologicznymi i nich. Pomiary dotyczą dysku z powłoką diamentopodobną (DLC) i stalowej kulki łożyskowej.

SŁOWA KLUCZOWE: struktura geometryczna powierzchni, mikroskopia sił atomowych, testy tribologiczne, powłoki diamentopodobne (DLC)

In order to assure reliable operation of machines and devices, it is necessary to increase the wear resistance of materials, from which individual parts of machines are made of. This goal can be achieved by applying special coatings that possess good mechanical, tribological and anti-corrosion properties.

Prior to application of new materials, their wear resistance should be investigated. It is usually conducted with the use of ball-disc testers that constitute a friction node (fig. 1).

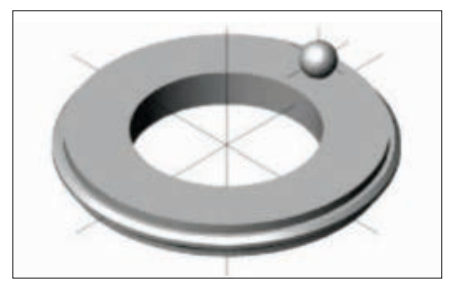

Fig. 1. Ball-disc type of friction node used in tribological tests

One of the criteria to assess the suitability of tested materials for particular applications is the quality of their surface $[1,2]$ before and after tribological tests.

A fundamental part of comprehensive study aiming at establishing an impact of thin coatings on properties of tribological systems is to measure the surface texture of materials at different stages of tribological tests. The measurements consist of the following operations:

- measurements of coating thickness,

- assessment of the texture of coated surface,

* Prof. dr hab. inż. Stanisław Adamczak (adamczak@tu.kielce.pl), mgr inż. Jacek Świderski (swiderski@tu.kielce.pl), mgr inż. Tomasz Dobrowolski (t.dobrowolski@tu.kielce.pl) - Wydział Mechatroniki i Budowy Maszyn Politechniki Świętokrzyskiej

\author{
DOI: https://doi.org/10.17814/mechanik.2017.12.193
}

- assessment of surface texture of friction node components after tribological tests.

The methods and instruments for measurements of surface topography continuously develop due to the fact that the surface quality is one of the most important factors determining the properties affecting the operation of elements such as glide capability, lubrication capability, wear resistance, fatigue strength, thermal and electrical conductivity, corrosion resistance, tightness and rigidity of fittings.

The most common methods for measuring the surface texture are contact profilometry, phase-shifting interferometry, coherence scanning interferometry, confocal microscopy, confocal chromatic microscopy, digital holography microscopy and atomic force microscopy [3].

Each of these methods has a different area of application resulting from its resolution, different measurement ranges and different capabilities of irregularities penetration $[4,5]$.

In this study, following methods were used to measure the surface texture of components of friction nodes: contact profilometry, coherence correlation interferometry and atomic force microscopy.

\section{Tested components}

Materials based on carbon that may crystallize in the diamond or graphite forms play an important role in contemporary technology. The term DLC (diamond-like carbon coatings) refers to a number of amorphous, in most cases hydrogenated, thin film materials having different properties depending on the method and conditions of their preparation. The A-C:H coatings occurring in this category are obtained from the chemical vapor deposition technique (CVD). The DLC coatings are used in the electronics industry as protective layers of magnetic hard disk drives, CD and DVD matrices, in the automotive industry as engine components coatings, in medicine for parts having contact with blood and orthopedic implants [6].

In the tribological node, the component containing coating is the disc, and the ball is a rolling element of the bearing made of $100 \mathrm{Cr} 6$ steel.

\section{Measuring instruments}

Contact profilometry is the method that is most often used to measure the surface texture. It uses a probe ended with a measuring tip. The vertical movement of the tip resulting from irregularities of the surface is converted into a measuring signal. The main limitation of the surface mapping is the tip geometry. Typical measuring tips are in the form of a cone with an apex angle $\alpha=60^{\circ}$ or $90^{\circ}$ and an apex rounding radius $r_{\text {tip }}=2 \mu \mathrm{m}$. Factors that are crucial for proper mapping of the surface are following: high resolution of the instrument in both horizontal and vertical 
axis, low measurement noise, good anti-vibration isolation, proper geometry and condition of the mapping blade. The instrument used for the measurements was the Form Talysurf PGI 1230 profilometer [7].

Coherence correlation interferometry $(\mathrm{CCl})$ based on an acquisition of images of interference fringes and their location during the vertical scanning combines a vertical scanning technique with optical interferometry. The limitation of this method for measuring the surface topography is the numerical aperture of the lens used, which limits the capability of measuring the steep slopes. The application of lens with too low aperture for the measurement of the surface with steep slopes results in the measurement with unmeasured points, indicated as white spots on the image of the surface topography. The disadvantage of this measurement method is the impact of optical properties of the material of the surface being measured on the measurement result-with the total absorption or light scattering the surface measurement is not possible. The instrument used for the measurements utilizing this method was Talysurf $\mathrm{CCl}$. This system enables the analysis of the surface geometrical structure with a vertical resolution of up to $10 \mathrm{pm}$ constant in the measurement range of $2.2 \mathrm{~mm}$.

Atomic force microscopy (AFM) uses mechanical interaction occurring between the top of the measuring tip and the surface being measured in order to assess the irregularities of the surface. Atomic Force Microscopes (AFM) belong to the group of Scanning Probe Microscopes (SPM). They are a group of instruments for testing the top layer of the components. These tests can be carried out in the range from a fraction of a nanometer to the level of a few micrometers.

The instrument for measuring the geometrical surface structure with a height of irregularities to $10 \mathrm{~mm}$ on the area of $90 \mu \mathrm{m} \times 90 \mu \mathrm{m}$ of measurement noise in $Z$ axis below $30 \mathrm{pm}$ is the Atomic Force Microscope AFM Dimension Icon. It enables measurements with the following modes: Scan Asyst, Tapping Mode and Contact Mode in both air and liquid environment.

\section{Measurement of the coating thickness}

The thickness of the diamond-like coatings are in the range of one to several micrometers. The instrument used to measure the thickness of the coating was Form Talysurf PGI 1230. The results of measuring the thickness of DLC coating are shown on fig. 2 and fig. 3.

Measurement of the disc surface with a coating prior to tribological tests

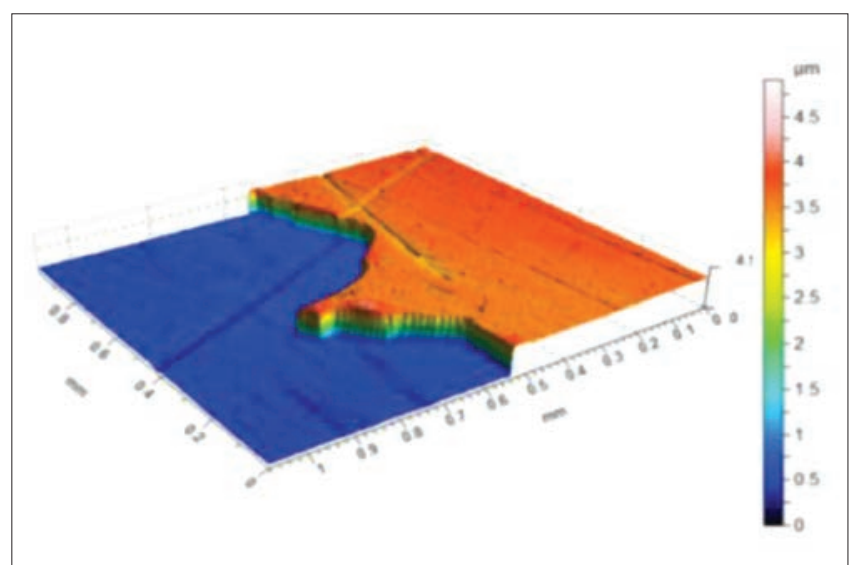

Fig. 2. Isometric image of the transition region without and with the DLC coating

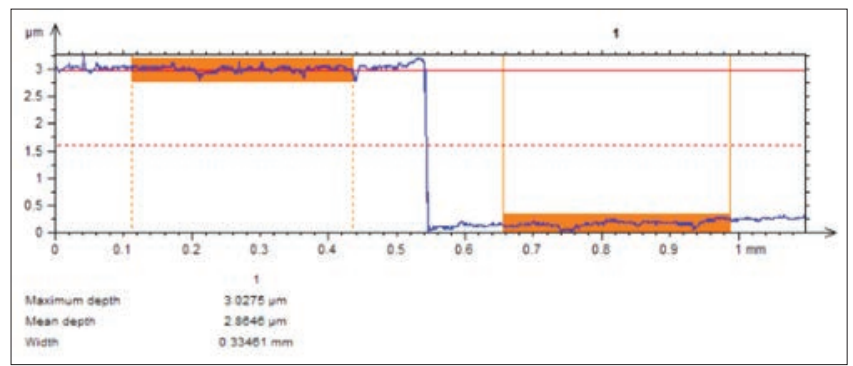

Fig. 3. Measurement of the coating thickness value

Measurement of the coating surface geometrical structure was carried out with the use of Talysurf $\mathrm{CCl}$ equipped with lens $\times 50$, thereby obtaining horizontal resolution of $0.36 \times 0.36 \mu \mathrm{m}$. An isometric image of the coating obtained after the measurement is shown in fig. 4 .

Measurement of the coating topography was conducted with the use of Dimension Icon atomic force microscope with a horizontal resolution of $0.10 \times 0.10 \mu \mathrm{m}$. The result of the measurement is shown in fig. 5 .

Analytical software enables a complete analysis of the surface topography by the use of various types of filters, the designation of distribution of the surface elevations, capacity curve, areal field parameters of roughness and the profile roughness parameters.

\section{Measurement of the disc surface with a coating after tribological tests}

The assessment of the surface geometrical structure of the disc with a coating after tribological tests involves imaging of the disc wear trace topography, which needs to be carried out using the method matched to the size and

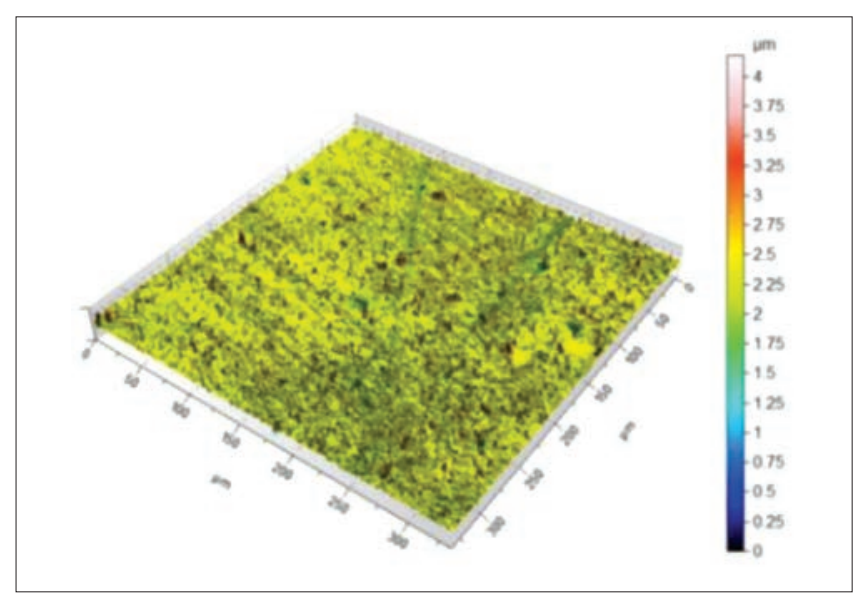

Fig. 4. Isometric image of DLC coating (Talysurf $\mathrm{CCl}$ )

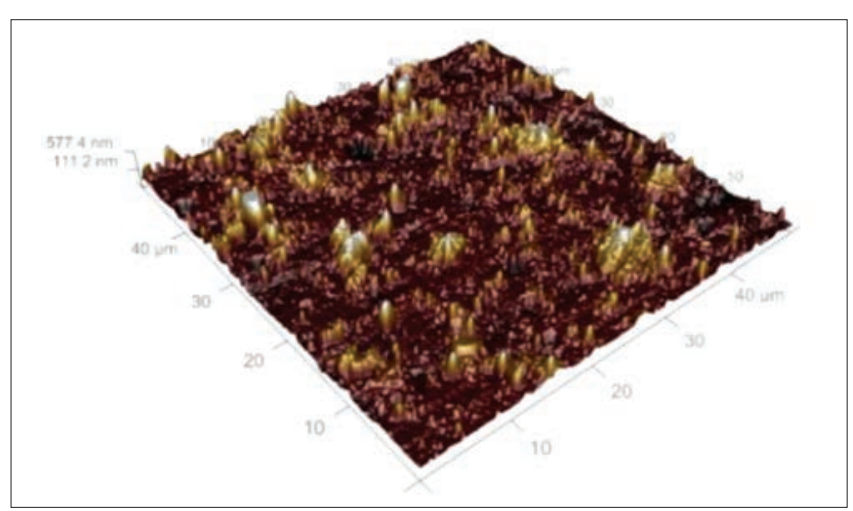

Fig. 5. Isometric image of the DLC coating (AFM Dimension Icon) 
geometry of the tested surface wear trace. In the case of the wear trace depth not exceeding $10 \mu \mathrm{m}$ and a width not exceeding $90 \mu \mathrm{m}$, atomic force microscope can be used. The measurement result of the disc wear trace conducted with the use of an atomic force microscope is shown in fig. 6 .

The most effective instrument for imaging the disc coating wear trace is the coherence correlation interferometry due to the short measurement time and the use of the "stitching" of individual measurements, thus there is a possibility of imaging the entire area of the disc - ball cooperation. Figure 7 shows an isometric image of the part of the DLC coating wear trace, while fig. 8 demonstrates maximum depth of the groove, height of the bead, and surface area of the groove and the bead determined on the selected profile.

Figure 9 shows the measurement of the surface with wear traces applying "stitching” of individual measurements. The measurement was used to calculate the volume of the groove - the amount of worn coating material during the tribological tests (fig. 10).

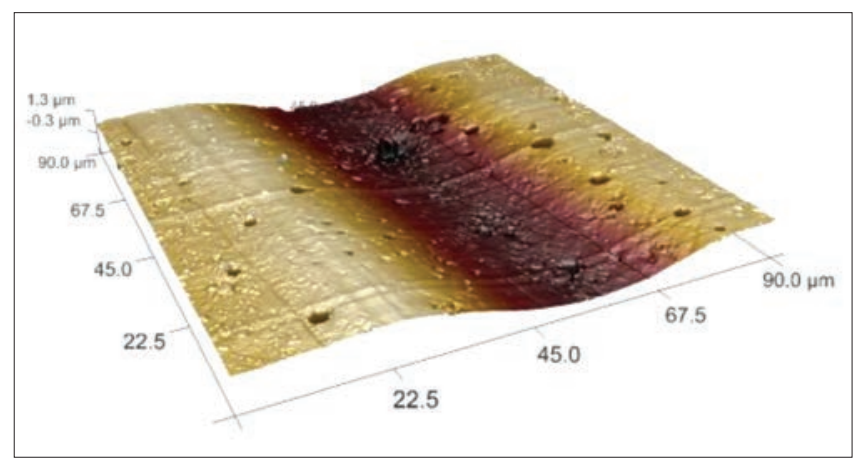

Fig. 6. Isometric image of the DLC coating wear trace (AFM Dimension Icon)

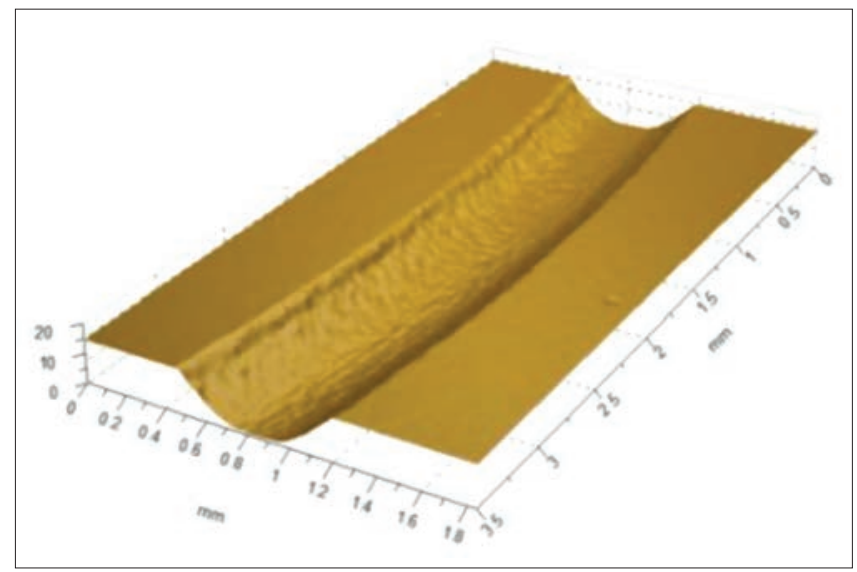

Fig. 7. Isometric image of the DLC coating wear trace (Talysurf CCI)

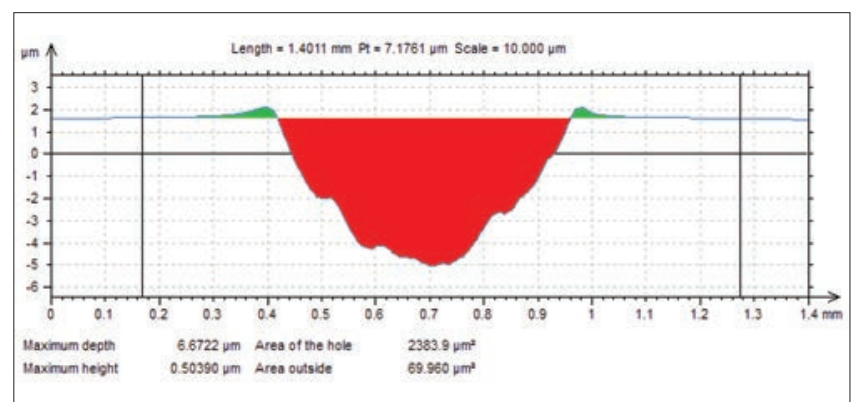

Fig. 8. Profile perpendicular to the direction of DLC coating wear (Talysurf $\mathrm{CCl}$ )

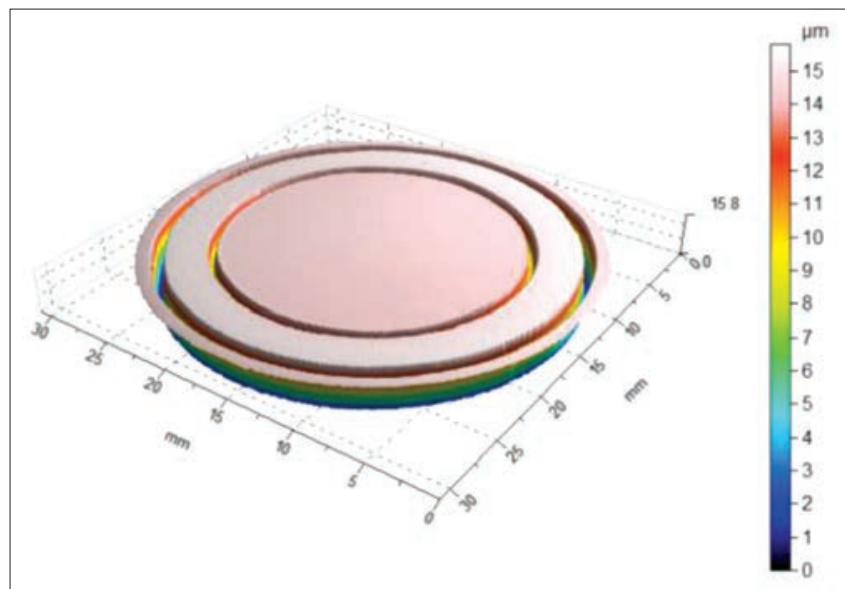

Fig. 9. Isometric image of the DLC coating surface with two homocentric wear traces (Talysurf CCl)

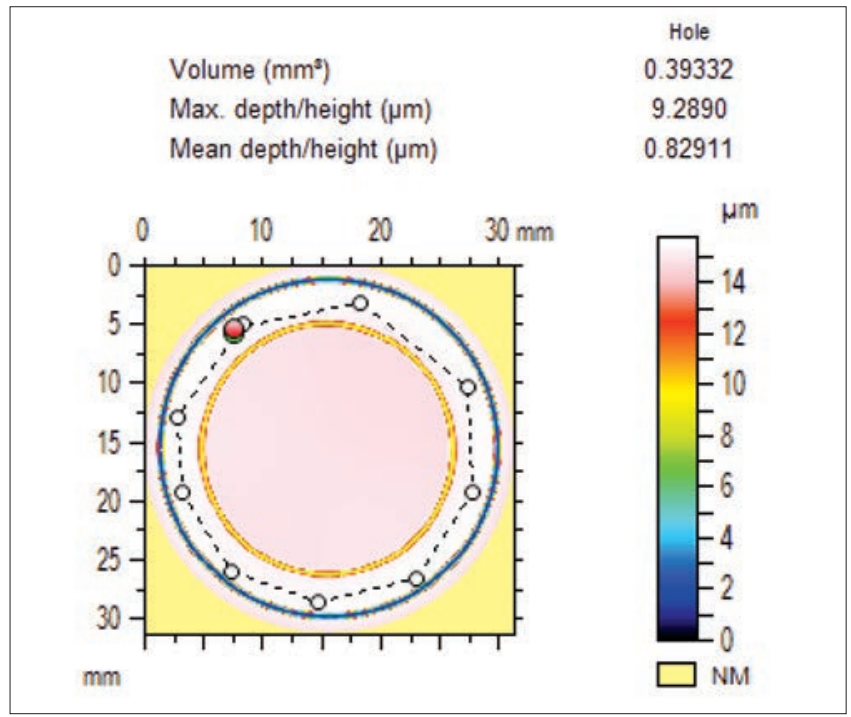

Fig. 10. Measurement of the groove volume (Talysurf $\mathrm{CCl}$ )

\section{Measurement of the ball surface after tribological tests}

The assessment of the ball wear after tribological tests was carried out with the use of coherence correlation interferometry. Figure 11 shows an isometric image of the ball. Figure 12 shows the parameters of worn ball surface and the distribution of elevations and the Abbott-Firestone curve.

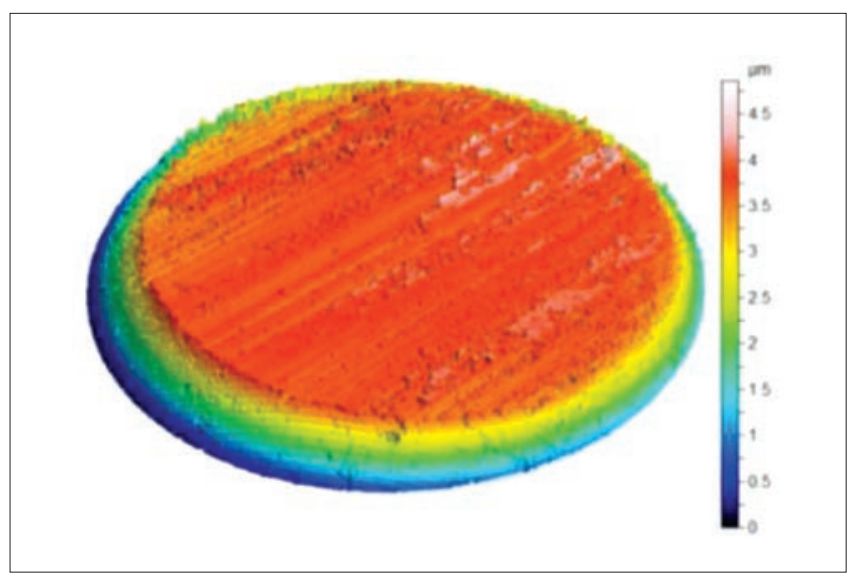

Fig. 11. Isometric image of the ball (Talysurf $\mathrm{CCl}$ ) 


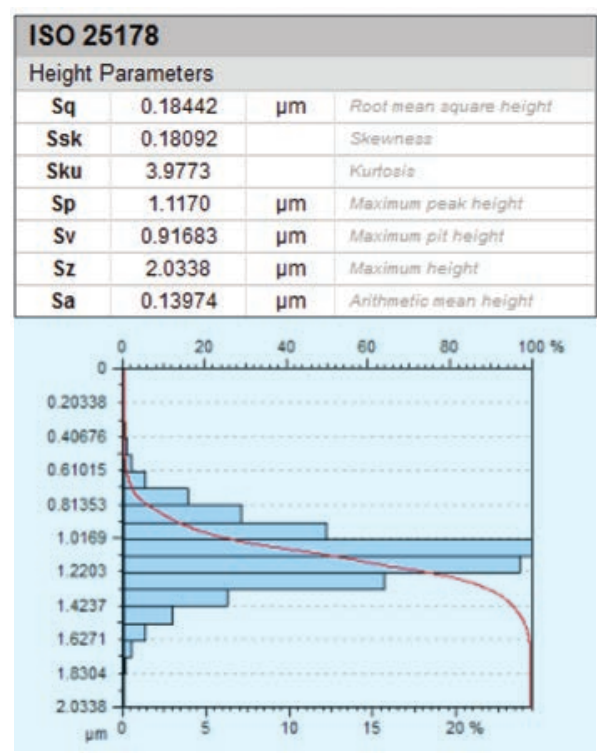

Fig. 12. Parameters, distribution of surface elevations and the AbbottFirestone curve

\section{Conclusions}

The development of new methods of surface texture measurements provides wide measurement capabilities in many areas of research. One of the elements of the results analysis obtained during the tribological tests is the assessment of the disc-ball friction node wear.

Selection of the appropriate method to assess the surface texture of the friction node components due to the capabilities and limitations of the particular methods and instruments is a prerequisite for reliable results. It is particularly important to observe the rules of good practice measurement guide in order to reduce the impact of major sources of errors on the measurement result. Therefore, it is important to know the factors affecting the measurement results when using particular measurement methods.

The measuring instruments for surface topography are equipped with analytical software that allows comprehensive assessment of the disc-ball friction node components both before and after tribological tests. It enables full visualization of the measurement results, calculation of areal field parameters and geometrical dimensions of the surface and profile.

The study constitutes a part of the project contract by Polish National Centre of Research and Development No. PBS2/A6/20/2013/NCBiR/24/10/2013 "Research and evaluation of reliability of modern methods of surface topography measurements in micro and nano scale".

\section{REFERENCES}

1. Adamczak S. „Pomiary geometryczne powierzchni. Zarysy kształtu falistość i chropowatość". Warszawa: WNT, 2008.

2. Wieczorowski M. „Wykorzystanie analizy topograficznej w pomiarach nierówności powierzchni”. Poznań: Wydawnictwo Politechniki Poznańskiej, 2009

3. Adamczak S., Świderski J., Wieczorowski M., Majchrowski R., Miller T., Łętocha A. „Założenia do oceny wiarygodności pomiarów topografii powierzchni w różnych skalach". Mechanik. 3 (2015): s. 81-87.

4. Miller T., Adamczak S., Świderski J., Wieczorowski M., Łętocha A. Gapiński B. "Influence of temperature gradient on surface texture measurements with the use of profilometry". Bulletin of the Polish Academy of Sciences. 65, 1 (2017): pp. 53-61.

5. Pawlus P., Wieczorowski M., Mathia T. "The errors of stylus methods in surface topography measurements". Szczecin: ZAPOL, 2014.

6. Madej M., Ozimina D., Kurzydłowski K., Płociński T., Wieciński P., Baranowicz P. "Diamond-like carbon coatings in biotribological applications". Kovove Materialy - Metallic Materials. 54, 3 (ROK ???): pp. 185-194.

7. Leach R. "Measurement Good Practice Guide No. 37 The measurement of surface texture using stylus instruments". Engineering Measurement Division National Physical Laboratory, 2014. 